\title{
ANTIOXIDANT AND ANTIMICROBIAL ACTIVITIES OF FERULIC ACID ESTERS FROM Ochrosia Oppositifolia
}

\section{Mehran Fadaei Nasab ${ }^{1}$, A.Hamid A.Hadi ${ }^{1}$ Ibrahim A. Najmuldeen ${ }^{1}$, Khalijah Awang ${ }^{1}$, Ali Dadolahi Sohrab ${ }^{2}$, Reza Farzin Ebrahimi ${ }^{3}$, Arash Rafat ${ }^{3}$, and Arash Khorasani $^{3}$}

${ }^{1}$ Department of Chemistry, Faculty of Science, University of Malaya, 50603 Kuala Lumpur, Malaysia, ${ }^{2}$ Department of Marine Environment, Faculty of Marine Natural Resources, Khorramshahr Marine Science ad Technology University, 669 Khorramshahr, Iran, ${ }^{3}$ Institute of Science and Biology, University Malaya, 50603 Kuala Lumpur, Malaysia.

Received in $5^{\text {th }}$ June 2011, accepted in revised form $21^{\text {th }}$ July 2011.

\begin{abstract}
Two ferulic acid esters namely (E)-methyl 3-(4'-hydroxy-3',5' dimethoxyphenyl) acrylate1 and (E)-methyl 18-((E)-3-(4'-hydroxy-3'methoxyphenyl)acryloyloxy)octadec-3-enoate ) 2, were isolated from Ochrosia oppositifolia. The compound $\mathbf{1}$, and $\mathbf{2}$ and the crude methanol and hexane extracts of Ochrosia oppositifolia showed a moderate in vitro antioxidant and antimicrobial activity.
\end{abstract}

(Keywords: Ochrosia oppositifolia, Apocynaceae, Ferulic acid esters, antimicrobial and antioxidant)

\section{INTRODUCTION}

Malaysia is known with its green tropical vegetation and forest [1]. The Malaysians has been reported to practice traditional and herbal remedies as an alternative choice in treatment of diseases [2]. Ochrosia oppositifolia belongs to Apocynaceae family [3], plants of this genus find wide use in the traditional system of medicine [4, 5]. It is an evergreen tree that can vary greatly in size, growing to a maximum height of $15 \mathrm{~m}$ or more. This species produces five-petalled white flowers with yellow centers. The flowers usually drop to the ground like confetti. The fallen flowers provide a clue to find the tree. The fruit comes in pairs, is elliptical in shape, and is about $5-8 \mathrm{~cm}$ long and turns yellow when it is ripe. The seed is about $10-20 \mathrm{~cm}$, apparently growing quite slowly [6].

\section{MATERIAL AND METHODS}

\section{General Experimental procedures}

CC was run on silica gel $60(40-63 \mu \mathrm{m})$. TLC was performed on aluminum and glass plates pre-coated with silica gel $60 \mathrm{~F}_{254}$ (Merck). ${ }^{1} \mathrm{H}$ NMR and ${ }^{13} \mathrm{C}$ NMR spectra were determined in
$\mathrm{CDCl}_{3}$ (JEOL JNM-FX400), UV spectra were recorded on a Shimadzu UV-160A spectrophotometer using $\mathrm{MeOH}$ as solvent. MS was obtained with Agilent 6530.

\section{Collecting of plant material}

The plant materials (barks) of Ochrosia oppositifolia (KL 5349) were collected from Pangkor Islands in 2007. The botanical identification was made by Mr.Teo Leong Eng, Faculty of Science, University of Malaya. Voucher specimens are deposited in the Herbarium of Chemistry Department, University of Malaya.

\section{Extraction and Isolation}

The extraction of the plant $(1.0 \mathrm{~kg})$ was carried out by extracted exhaustively with hexane after moistened with $10 \%$ ammonia solution for 48 hours to remove waxes and fats. Then the extract was dried on the rotary evaporator. The plant material was dried and again wetted with $10 \%$ ammonia solution and left for overnight. They were then re-extracted successively with dichloromethane $\left(\mathrm{CH}_{2} \mathrm{Cl}_{2}\right)$ and methanol $(\mathrm{MeOH})$. After removal of the solvents, the 
hexane crude extract (1.2 g), dichloromethane $(15 \mathrm{~g})$ and methanol (15 g) were obtained.

\section{Total Phenolic Content Evaluation}

A protocol based on the Folin-Ciocalteau method described by Slinkard and Singleton [7] was employed to determine the total amount of present phenolic compounds in various crude extracts of Ochrosia oppositifolia. Methanol and hexane crude extracts at concentration of 10 $\mathrm{mg} / \mathrm{mL}$ were added to $100 \mu \mathrm{L}$ of $2 \mathrm{~N}$ FolinCiocalteu reagent. Sodium carbonate solution $(300 \mu \mathrm{L})$ at concentration of $0.2 \mathrm{mg} / \mathrm{mL}$ was added after the final volume of mixture was made up to $1600 \mu \mathrm{L}$ using distilled water. The mixture was then incubated at $37{ }^{\circ} \mathrm{C}$ for $45 \mathrm{~min}$ before the absorbance of solutions was measured at $760 \mathrm{~nm}$ using a spectrophotometer. Lastly, the total phenolic contents were expressed as a gallic acid equivalent (GAE) based on Folin-Ciocalteau calibration curve using gallic acid as the standard.

\section{Antioxidant activity}

\section{Radical Scavenging Capacity Assay}

DPPH (2,2-diphenyl-1-picrylhydrazil) free radical scavenging capacity assay was obtained from the protocol described by Rafat [8]. DPPH $(950 \mu \mathrm{L})$ in concentration of $90 \mu \mathrm{M}$ was mixed with $50 \mu \mathrm{L}$ of the plant extracts and pure compounds $(10 \mathrm{mg} / \mathrm{mL})$ and the volume was adjusted to $4 \mathrm{~mL}$ using $95 \%$ ethanol before incubation at room temperature in the dark for 120 min. Scavenging of DPPH reduced the colour of the solution and was measured using a spectrophotometer at $515 \mathrm{~nm}$. Comparison of the reduction of the colour by examined samples with the blank (solution without plant crude extract) was used to measure the potential of scavenging capacity of our plant crude extracts using the following equation.

Radical Scavenging Capacity $(\%)=[($ Blank Sample A) / Blank] x 100

\section{Superoxide dismutase (SOD) Determination Assay \\ SOD determination kit was used to determine the superoxide dismutase (SOD) activity of prepared crude extracts. The procedure was carried out based on the manual descript of the kit. Plant crude extracts and pure compounds $(20 \mu \mathrm{L})$ of the concentration of $10 \mathrm{mg} / \mathrm{mL}$ were added to}

$200 \mu \mathrm{L}$ of the kit Working Solution. The mixture after a gentle shaking incubated at $37{ }^{\circ} \mathrm{C}$ for 20 min after adding $20 \mu \mathrm{L}$ the kit Enzyme Working Solution. The absorbance of the mixtures was measured at $450 \mathrm{~nm}$ using a microplate reader and the SOD activity was calculated using the following equation.

Percentage of Inhibition (SOD Activity) = \{[(blank 1 - blank 3) - (Sample A - Sample A's blank 2)] / (blank 1 - blank 3) \} x 100

Blank 1 was the mixture of Working Solution $(200 \mu \mathrm{L})$ and Enzyme Working Solution $(20 \mu \mathrm{L})$ containing $20 \mu \mathrm{L}$ double distilled water $\left(\mathrm{ddH}_{2} \mathrm{O}\right)$. Blank 2 contained the plant extract $(20 \mu \mathrm{L})$ with Working Solution $(200 \mu \mathrm{L})$ and $(20 \mu \mathrm{L})$ Dilution Buffer while $\mathrm{ddH}_{2} \mathrm{O}(20 \mu \mathrm{L})$ was replaced the plant crude extracts in the blank 3 . Ascorbic acid $(1 \mathrm{mg} / \mathrm{mL})$ and $1 \mathrm{mg} / \mathrm{mL}$ of Tert-butylated hydroxytoluene (BHT) were employed as the positive controls in this study.

\section{Antibacterial Activity Assay}

The antibacterial potential of our samples was studied using the paper disc diffusion method of Kil [9]. Two Gram-Negative pathogenic bacteria (Escherichia coli and Pseudomonas aeruginosa) and two Gram-Positive pathogenic bacteria (Staphylococcus aureus and Bacillus cereus) were obtained from Microbiology Division of Institute of Biological Sciences, University of Malaya and then grown in Nutrient Broth medium to yield a final concentration of $10^{7}$ $\mathrm{CFU} / \mathrm{mL}$. The test bacteria $(0.1 \mathrm{~mL})$ were streaked on whole Mueller Hinton medium plates using sterile swab cotton. Sterilized filter paper discs were soaked in $\mathrm{MeOH}, \mathrm{DCM}$ and Hexane crude extracts $(100 \mathrm{mg} / \mathrm{mL})$ as well as pure compounds $(10 \mathrm{mg} / \mathrm{mL})$ and were then placed in the centre of test bacteria plates. The plates were incubated for $24 \mathrm{~h}$ and diameter of the produced inhibition zone was measured. Tetracycline disc $(30 \mu \mathrm{g})$ and PBS were used as the positive and negative controls respectively.

\section{Statistical Analysis}

All experiments were carried out in triplicate. One-way analysis of variance (ANOVA) was used to analyze the data using SPSS version 15. The means were compared by Duncan's Multiple Range Test (DMRT) and $\mathrm{p}<0.05$ was considered to indicate statistical significance. 


\section{RESULTS AND DISCUSSION}

Repeated column chromatography of the $\mathrm{MeOH}$ extract of the bark of Ochrosia oppositifolia led to the isolation of two ferulic acid esters. The structure of compound 1, (E)-methyl 3-(4'hydroxy-3',5'-dimethoxyphenylacrylate and the compound 2, (E)-methyl 18-((E)-3-(4'-hydroxy3-methoxyphenyl)acryloyloxy)octadec-3-enoate were deduced from their spectral data and also by comparing their spectral data with those previously reported.

Compound $\mathbf{1}$ was isolated as a white amorphous solid. The mass spectrum revealed a molecular ion peak at $\mathrm{m} / \mathrm{z} 238.09[\mathrm{M}]^{+}$corresponding to the molecular formula of $\mathrm{C}_{12} \mathrm{H}_{14} \mathrm{O}_{5}$. The $\mathrm{UV}$ spectrum revealed maximum at 196, 273 and 328 $\mathrm{nm}$, indicating the presence of highly conjugated double bonds. The IR spectrum showed an absorption peak at $3401 \mathrm{~cm}^{-1}$ which characterised for hydroxyl group. In addition, an absorption peak was observed at $1704 \mathrm{~cm}^{-1}$ which indicated the presence of the conjugated carbonyl group.

The ${ }^{1} \mathrm{H}$ NMR showed the presence of two $\mathrm{sp}^{2}$ methine groups resonated at $\delta 6.29$ and 7.59 as a doublet with coupling constant $16 \mathrm{~Hz}$ which were attributable to methine protons at $\mathrm{C}-2$ and C-3 of acrylate group, respectively. The two aromatic protons resonated at $\delta 6.77$ and 6.77 as a siglet belongs to proton at C-2' and C-6' respectively. It also exhibited three singlet peaks with three protons at $\delta 3.92,3.91$ and 3.79 which were attributable to methoxyl groups at C-3', C5' and C-1, respectively. The hydroxyl group was resonated at $\delta 5.80$ as a broad singlet. In the ${ }^{13} \mathrm{C}$ NMR spectrum, There are twelve carbon signals consist of three methoxyl groups, one carbonyl group, four $\mathrm{sp}^{2}$ methine carbons and four $\mathrm{sp}^{2}$ quaternary carbons. The carbonyl carbon resonated at $\delta 167.6$ whereas two $\mathrm{sp}^{2}$ carbons $\mathrm{C}$ 2 and C-3 appeared at $\delta 115.6$ and 145.2. The equivalent carbons, C-3' and C-5' bearing methoxyl group resonated at $\delta 147.2$ Both methoxyl carbon at C-3' and C-5' appeared at $\delta$ 56.4 and the methoxyl ester group resonated at $\delta$ 51.7. The C-4' bearing hydroxyl group appeared at $\delta$ 137.1. The quarternary aromatic carbon resonated at $\delta 125.9$ was attributable to $\mathrm{C}-1$ ' . By comparing ${ }^{1} \mathrm{H}$ NMR and ${ }^{13} \mathrm{C}$ NMR spectral data with those that have been previously reported, it is confirm that compound $\mathbf{1}$ was $(E)$-methyl 3(4'-hydroxy-3',5'-dimethoxyphenylacrylate.<smiles>COC(=O)/C=C/c1cc(OC)c(O)c(OC)c1</smiles>

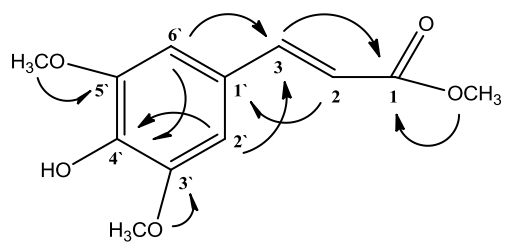

HMBC correlation of compound 1

Compound $\mathbf{2}$ was isolated as a white amorphous solid. The mass spectrum revealed a molecular ion peak at $\mathrm{m} / \mathrm{z} 488.3[\mathrm{M}]^{+}$corresponding to the molecular formula $\mathrm{C}_{29} \mathrm{H}_{44} \mathrm{O}_{6}$. The $\mathrm{UV}$ spectrum revealed maximum at 196, 273 and $328 \mathrm{~nm}$ and the IR spectrum showed an absorption band at 3431 $\mathrm{cm}^{-1}$ indicating the presence of $\mathrm{OH}$ group. In addition, two peaks were observed at 1711 and $1738 \mathrm{~cm}^{-1}$ which implied the presence of two carbonyl groups.

The ${ }^{1} \mathrm{H}$ NMR spectrum indicated the presence of three aromatic protons at $\delta 7.10,7.01$ and 6.89 attached to C-6", C-2" and C-5", respectively. There were two singlet peaks appeared at $\delta 3.91$ and 3.64 attributed to two methoxyl groups attached to C-3" and C-18' respectively. The cross peak of COSY showed one coupling set (H-3 to H$2)$. This was confirmed by the existence of two sets of doublet $(J=16 \mathrm{~Hz})$ in the ${ }^{1} \mathrm{H} \mathrm{NMR}$ at $\delta 7.50$ and 6.27 which corresponded to the resonances of $\mathrm{H}-3$ and $\mathrm{H}-2$, respectively. The $\mathrm{HMBC}$ correlation between $\mathrm{H}-14$ ' to $\mathrm{C}-15$ ', C-16' established the position of double bond in the long chain. The ${ }^{13} \mathrm{C}$ 
NMR and DEPT showed the presence of 29 carbon atoms in the molecule which consists of three quaternary aromatic carbons, three aromatic protons, four $\mathrm{sp}^{2}$ methines, fourteen methylenes, two methoxyl groups and two carbonyl esters. The two carbonyls appeared at $\delta 174.4$ and 167.4 which were attributable to $\mathrm{C}-18^{\circ}$ and $\mathrm{C}-1$ respectively. The $\mathrm{sp}^{2}$ methines appered at $\delta 6.27$, $7.50,5.30,5.31$ belongs to the proton at $\mathrm{C}-2,3,15$ ' and 16', respectively. From the spectral data, it is confirm that compound 2 was (E)-methyl 18-((E)3-(4'-hydroxy-3'-methoxyphenyl)acryloyloxy octadec-3-enoate ).

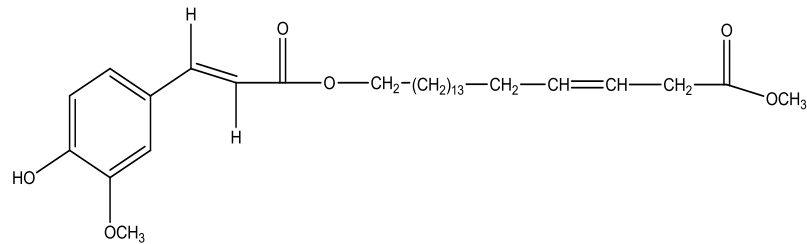

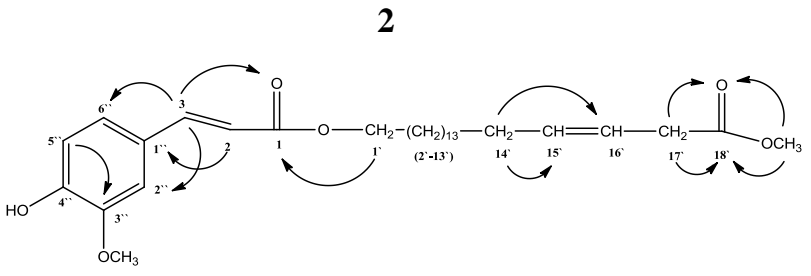

HMBC correlation of compound 2

Table 1. ${ }^{1} \mathrm{H}$ NMR $\left[400 \mathrm{MHz},{ }^{1} \mathrm{H}(\mathrm{J}, \mathrm{Hz})\right]$ and ${ }^{13} \mathrm{C}$ NMR $\left[100 \mathrm{MHz}, \delta_{\mathrm{C}}\right]$ of $(\mathbf{1})$ in $\mathrm{CDCl}_{3}$

\begin{tabular}{ccc}
\hline Position & ${ }^{1} \mathrm{H}, \delta_{\mathrm{H}}, J$ in $\mathrm{Hz}$ & ${ }^{13} \mathrm{C}, \delta_{\mathrm{c}}$ \\
\hline 1 & - & 167.6 \\
2 & $6.29, \mathrm{~d}, 16$ & 115.6 \\
3 & $7.59, \mathrm{~d}, 16$ & 145.2 \\
1, & - & 125.9 \\
2 & $6.77, \mathrm{~s}$ & 105.1 \\
3, & - & 147.2 \\
& - & \\
4 & - & 137.1 \\
5 & $6.77, \mathrm{~s}$ & 147.2 \\
6 & $3.79, \mathrm{~s}$ & 105.1 \\
$1^{\prime}-\mathrm{OCH}_{3}$ & $3.92, \mathrm{~s}$ & 51.7 \\
$3^{\prime}-\mathrm{OCH}_{3}$ & $3.91, \mathrm{~s}$ & 56.4 \\
$5^{\prime} \mathrm{OCH}$ & $5.80, \mathrm{bs}$ & 56.4 \\
$4^{\prime}-\mathrm{OH}$ & & - \\
\hline
\end{tabular}


Malaysian Journal of Science 30 (2): 154-160 (2011)

Table 2. ${ }^{1} \mathrm{H}$ NMR $\left[400 \mathrm{MHz},{ }^{1} \mathrm{H}(\mathrm{J}, \mathrm{Hz})\right]$ and ${ }^{13} \mathrm{C} \mathrm{NMR}\left[100 \mathrm{MHz}, \delta_{\mathrm{C}}\right]$ of $(2)$ in $\mathrm{CDCl}_{3}$

\begin{tabular}{|c|c|c|}
\hline Position & ${ }^{1} \mathrm{H}, \delta_{\mathrm{H}}, J$ in $\mathrm{Hz}$ & ${ }^{13} \mathrm{C}, \delta_{\mathrm{c}}$ \\
\hline 1 & - & \\
\hline 2 & $6.27, \mathrm{~d}, 16$ & 115.7 \\
\hline 3 & $7.50, \mathrm{~d}, 16$ & 144.7 \\
\hline $1 "$ & - & 127.1 \\
\hline $2 "$ & $7.01, \mathrm{~s}$ & 109.3 \\
\hline $3 "$ & - & 146.8 \\
\hline $4 "$ & - & 147.9 \\
\hline $5 "$ & $6.90, \mathrm{~d}, 8.2$ & 114.7 \\
\hline $6 "$ & $7.10, \mathrm{~d}, 8.2$ & 123.1 \\
\hline 1 & $4.10, \mathrm{t}, 6.8$ & 64.6 \\
\hline $2^{\prime}-13^{\prime}$ & $1.28-1.58$ & $29.2-29.7$ \\
\hline 14 & $2.1, \mathrm{~d}, 5.4$ & 29.8 \\
\hline $15^{\prime}$ & $5.3, \mathrm{~m}$ & 129.9 \\
\hline $16^{\prime}$ & $5.3, \mathrm{~m}$ & 130.1 \\
\hline $17^{\prime}$ & $2.3, \mathrm{~m}$ & 34.02 \\
\hline 18 & - & 174.4 \\
\hline $\mathrm{C} 18^{\prime}-\mathrm{OCH}_{3}$ & $3.64, \mathrm{~s}$ & 51.5 \\
\hline $\mathrm{C} 3$ "- $-\mathrm{OCH}_{3}$ & $5.90, \mathrm{~s}$ & 56.01 \\
\hline $\mathrm{OH}$ & $5.90, \mathrm{bs}$ & - \\
\hline
\end{tabular}

\section{Total Phenolic Content}

Table 3. Total phenolic contents of extracts

\begin{tabular}{|l|c|}
\hline Crude extract & $\begin{array}{l}\text { Gallic Acid Equivalents } \\
(\mathrm{g} / 100 \mathrm{~g})\end{array}$ \\
\hline Methanol & $5.08 \pm 0.164^{\mathrm{b}}$ \\
\hline Hexane & $16.09 \pm 0.180^{\mathrm{a}}$ \\
\hline Dichloromethane & $4.15 \pm 0.163^{\mathrm{c}}$ \\
\hline
\end{tabular}

Table 3 showed that the phenolic compounds are higher in the hexane extract compared to methanol and dichloromethane extracts.

\section{Antioxidant Assays}

DPPH Radical Scavenging Activity Assay

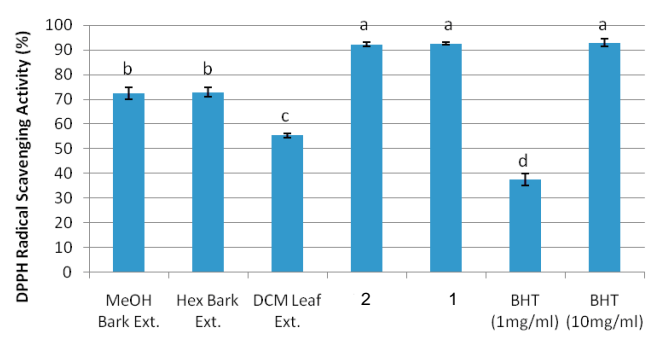

Figure 1. Antioxidant activity of compounds 1, 2 and crude extracts isolated from Ochrosia oppositifolia 
Figure 1 showed the antioxidant activity of crude extracts and isolated compounds measured using DPPH scavenging activity assay and it is presented as percentage value. BHT ( 1 and $10 \mathrm{mg} / \mathrm{mL})$ were applied as the positive controls. The data were analyzed by one-way ANOVA and the DPPH scavenging activity percentage means of samples were compare by Duncan's Multiple Comparison Test (DMCT). Samples labeled with different letters are significantly different $(\mathrm{p}<0.05)$.

The results showed that the methanol and hexane extracts have equal activity when antioxidant assay was performed by DPPH Radical Scavenging method. The antioxidant activity of the crude extracts and compound $\mathbf{1}$ and $\mathbf{2}$ are slightly lower compared with positive control $(10 \mathrm{mg} / \mathrm{mL})$.

\section{SOD Assay}

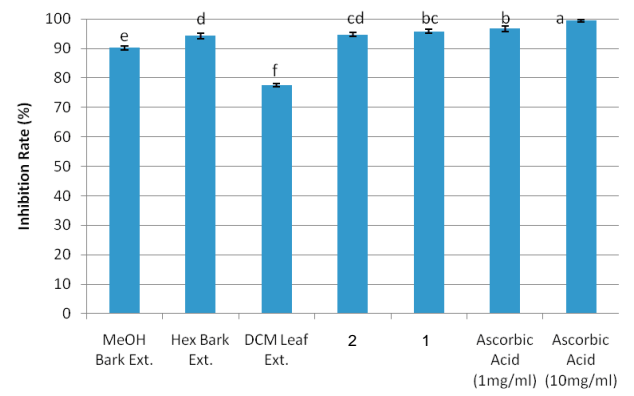

Figure 2. Antioxidant activity using SOD assay

Figure 2 showed the antioxidant activity of crude extracts and isolated compounds measured using superoxide dismutase (SOD) assay and the results are presented as percentage of inhibition rate. Ascorbic acid ( 1 and $10 \mathrm{mg} / \mathrm{mL}$ ) were used as the positive control. The data were analyzed by oneway ANOVA and the inhibition rate means of samples were compare by Duncan's Multiple Comparison Test (DMCT). Samples labeled with different letters are significantly different $(\mathrm{p}<$ $0.05)$.

The results showed that higher activity has been observed in methanol and hexane extracts and compounds $\mathbf{1}$ and $\mathbf{2}$ have the same activity with ascorbic acid.

\section{Antibacterial Activity Assay}

Table 4 showed the Inhibition effect of 100 $\mathrm{mg} / \mathrm{mL}$ of plant extracts and $1.0 \mathrm{mg} / \mathrm{mL}$ of isolated compounds against the growth of four pathogenic bacteria. The results indicated that there were no significant antibacterial activity shown by the crude extracts and isolated compounds.

Table 4. Inhibition effect of $100 \mathrm{mg} / \mathrm{mL}$ of plant extracts and $1 \mathrm{mg} / \mathrm{ml}$ of isolated compounds against the growth of four pathogenic bacteria

\begin{tabular}{|l|c|c|c|c|c|c|c|}
\hline \multirow{2}{*}{ Bacteria } & \multicolumn{5}{|c|}{ Inhibition Zone (mm) } \\
\cline { 2 - 7 } & $\begin{array}{c}\text { MeOH Bark } \\
\text { Ext. }\end{array}$ & $\begin{array}{c}\text { Hex Bark } \\
\text { Ext. }\end{array}$ & $\begin{array}{c}\text { DCM Leaf } \\
\text { Ext. }\end{array}$ & $\begin{array}{c}\text { Compound } \\
2\end{array}$ & $\begin{array}{c}\text { Compound } \\
1\end{array}$ & $\begin{array}{c}\text { Tetracycline } \\
(30 \mathrm{\mu g})\end{array}$ \\
\hline Escherichia coli & 9 & 11 & 8 & 8 & 8 & $21 \mathrm{~mm}$ \\
\hline $\begin{array}{l}\text { Staphylococcus } \\
\text { aureus }\end{array}$ & 10 & 11 & 10 & - & - & $35 \mathrm{~mm}$ \\
\hline $\begin{array}{l}\text { Pseudomonas } \\
\text { aeruginosa }\end{array}$ & - & - & - & 8 & 8 & $18 \mathrm{~mm}$ \\
\hline Bacillus cereus & 10 & 10 & - & - & - & $22 \mathrm{~mm}$ \\
\hline
\end{tabular}

\section{CONCLUSION}

Two ferulic acid esters have been isolated from the bark of Ochrosia oppositifolia. The crude extracts and the esters $\mathbf{1}$ and $\mathbf{2}$ have shown moderate antioxidant activity but there were no antibacterial activity was observed.

\section{ACKNOWLEDGEMENT}

We would like to thank to the University of Malaya for the research grant.

\section{REFERENCES}

1. Najib N., Takahisa F., Somei K., (1999) Antimalaria activity of extracts of Malaysian medicinal plants. J Ethnopharmacology, 64: 249254

2. Muhammad Z., Mustafa A.M., (1994) Traditional Malay Medicinal Plants. Fajar Bakti, Malaysia

3. Tadeusz A., (2007) Alkaloid chemistry, biological significance, applications and ecological role. Elsevier Science, United Kingdom 
4. Ahmad ., Thomas N.F., Hadi A.H.A., Mukhtar M.R., Morita H., Awng K., (2010) Oppositinines A and B: new vasorelaxant $\beta$ - carboline alkaloids from Neisoperma oppositifolia. Chem Pharm Bull $58: 8$

5. Kisakurek M.V., leeuwenberg A., (1983) A chemataxonomic in vestigation of the plant families of Apocynaceae, Loganiaceae and Rubiaceae by their Indole alkaloid content. Hobsons Press, Australia, pp 211-376

6. Peube N.L., Koch M. (1972) Alcaloides des Ecorces d Ochrosia oppositifolia. Phytochemistry 11:2109-2111

7. Slinkard, K., \& Singleton, V. L., (1977) Total phenol analyses: automation and comparison with manual methods, Am. $J$. Enol. Vitic 28:49-55

8. Rafat, A., Philip, K., \& Muniandy, S., (2010) Antioxidant potential and content of phenolic compounds in ethanolic extracts of selected parts of Andrographis paniculata, J. Med. Plants Res 4(3): 197-

9. Kil, H.Y., Seong, E.S., Ghimire, B.K., Chung, I.M., Kwon, S.S., Goh, E.J., Heo, K., Kim, M.J., Lim, J.D., Lee, D. and Yu, C.Y., (2009) Antioxidant and antimicrobial activities of crude sorghum extract. Food Chemistry. 115: 1234-1239. 
Malaysian Journal of Science 30 (2): 154-160 (2011) 